\title{
Population structure of the squid Doryteuthis pealeii on the eastern coast of the USA: Comment on Shaw et al. (2010)
}

\author{
Gabriele Gerlach ${ }^{1}$, Kendra C. Buresch ${ }^{2, *}$, Roger T. Hanlon ${ }^{2}$ \\ ${ }^{1}$ Institut für Biologie und Umweltwissenschaften, Carl von Ossietzky Universität Oldenburg, Carl von Ossietzky Str. 9-11, \\ 26111 Oldenburg, Germany \\ ${ }^{2}$ Marine Resources Center, Marine Biological Laboratory, 7 MBL Street, Woods Hole, Massachusetts 02543, USA
}

\begin{abstract}
A recent article by Shaw et al. (2010; Mar Ecol Prog Ser 408:117-127) reported no genetic differences among Doryteuthis pealeii samples collected along the eastern coast of the USA, whereas Buresch et al. (2006; Mar Ecol Prog Ser 310:263-270) reported 5 discrete populations in this same sampling area. Here we address the 3 possible reasons given by Shaw et al. (2010) for the discrepancy between their and our results, and provide results from additional analyses to support our arguments. $D$. pealeii is an important commercial species and a better understanding of its population structure is necessary before considering it as a single population for management purposes.
\end{abstract}

KEY WORDS: Squid $\cdot$ Population genetics $\cdot$ Fisheries management

Resale or republication not permitted without written consent of the publisher

\section{Discrepancy between datasets}

Shaw et al. (2010) reported no genetic differences among Doryteuthis pealeii samples collected along the eastern coast of the USA, whereas in Buresch et al. (2006), we reported 5 discrete populations in this same sampling area. Both groups used microsatellite genetic markers for their analyses. Shaw et al. (2010) suggest several possible reasons for this discrepancy: (1) sample size differences between the 2 studies, (2) different analysis methods leading to incorrect treatment of null alleles, or (3) temporal instability between years of sampling.

\section{Sample size and data analysis}

Sample size differences seem unlikely to be the cause of the discrepancy between the 2 studies. Shaw et al. (2010) had an average of 75 individuals per sample, whereas in Buresch et al. (2006), we had an average of 50 individuals per sample. Sample sizes of 50 are common in population genetics - this is a large enough sample size to accurately represent each population (Gerlach et al. 2010).

Our microsatellite data were analyzed carefully using the most current technology available at the time of the study (detailed methods in Buresch et al. 2006). Particular care was taken to correctly score allele sizes. Fragment sizes were determined both by comparison to commercial size standards as well as by repeatedly running samples with alleles of known size on each gel to assure correct fragment length. Allele lengths that could not be determined the first time were repeatedly run until unequivocal assignment could be made.

\section{Null alleles}

To address the possibility that null alleles were responsible for erroneously depicting population dif- 
Table 1. Doryteuthis pealeii. Differences among population samples from the NW Atlantic. $F_{\text {ST }}$ values were corrected for null alleles using MICROCHECKER and FreeNA. *Populations are similar, based on the $D_{\text {EST }}$ value. ${ }^{* *}$ Only FreeNA shows that the populations are genetically similar. Refer to Buresch et al. (2006) for station locations

\begin{tabular}{|c|c|c|c|c|c|c|}
\hline $\begin{array}{l}\text { Popula- } \\
\text { tion } 1\end{array}$ & $\begin{array}{l}\text { Popula- } \\
\text { tion } 2\end{array}$ & $\begin{array}{c}F_{\mathrm{S}} \\
\text { MICRO- } \\
\text { CHECKER }\end{array}$ & T $\overline{\text { FreeNA }}$ & $D_{\text {EST }}$ & $\begin{array}{c}\text { Confidenc } \\
-95 \%\end{array}$ & $\begin{array}{l}\text { e interval } \\
+95 \%\end{array}$ \\
\hline Stn 1 & $\operatorname{Stn} 2$ & 0.086 & 0.088 & 0.273 & 0.208 & 0.353 \\
\hline Stn 1 & Stn 3 & 0.048 & 0.053 & 0.227 & 0.179 & 0.278 \\
\hline Stn 1 & $\operatorname{Stn} 4$ & 0.081 & 0.076 & 0.296 & 0.235 & 0.360 \\
\hline Stn 1 & $\operatorname{Stn} 5$ & 0.081 & 0.079 & 0.279 & 0.223 & 0.342 \\
\hline Stn 1 & $\operatorname{Stn} 7$ & 0.047 & $0.056^{* *}$ & 0.227 & 0.162 & 0.300 \\
\hline Stn 2 & Stn 3 & 0.038 & 0.038 & 0.116 & 0.064 & 0.188 \\
\hline Stn 2 & $\operatorname{Stn} 4$ & 0.052 & 0.053 & 0.151 & 0.100 & 0.221 \\
\hline Stn 2 & Stn 5 & 0.038 & 0.041 & 0.122 & 0.061 & 0.205 \\
\hline Stn 2 & $\operatorname{Stn} 7$ & 0.030 & 0.026 & 0.112 & 0.052 & 0.193 \\
\hline Stn 3 & Stn 4 & 0.024 & 0.023 & 0.068 & 0.028 & 0.114 \\
\hline Stn 3 & Stn 5 & 0.020 & 0.016 & 0.053 & 0.017 & 0.099 \\
\hline Stn 3 & $\operatorname{Stn} 7$ & 0.012 & 0.011 & $0.047^{*}$ & -0.008 & 0.104 \\
\hline $\operatorname{Stn} 4$ & Stn 5 & 0.052 & $0.055^{* *}$ & 0.161 & 0.108 & 0.212 \\
\hline Stn 4 & Stn 7 & 0.028 & 0.024 & 0.074 & 0.015 & 0.141 \\
\hline Stn 5 & $\operatorname{Stn} 7$ & 0.032 & 0.027 & 0.081 & 0.029 & 0.148 \\
\hline
\end{tabular}

ral stability across years and seasons (Table 2). All samples were statistically different from each other, although with low $D_{\text {EST }}$ values (Jost 2008) and $F_{\text {ST }}$ values. Interestingly, the 2 summer samples were most different from each other $(13 \%$ between 1999 and 2000).

The differences between years can most likely be explained by yearly differences in dispersal patterns of larvae as well as differences in migration routes of adults. This suggests that Doryteuthis pealeii does not exhibit natal homing along the coast of Cape Cod (Massachusetts, USA). Instead, squids along the northeastern coast of the USA appear to be traveling together in related groups, as evidenced by the population differentiation observed along the coast in the samples collected by Buresch et al. (2006). As pointed out by Shaw et al. (2010), the extreme annual fluctuations in recruitment success and abundance in squid populations (Boyle \& ferentiation, we reanalyzed our data using FreeNA (Chapuis \& Estoup 2007), the software used by Shaw et al. (2010). Our original analysis was done after correcting for null alleles using MICROCHECKER (van Oosterhout et al. 2004). Balancing for null alleles with FreeNA ultimately yielded almost the same differentiation between populations as with MICROCHECKER (Table 1). The only exceptions were the 2 comparisons Stn 7 vs. Stn 1 and Stn 4 vs. Stn 5, where populations were significantly different from each other when MICROCHECKER was used, but not when FreeNA was applied; however the $F_{\mathrm{ST}}$ values remained very similar (Table 1 ). The $D_{\text {EST }}$ values, which more accurately reflect genetic differentiation (Gerlach et al. 2010), showed statistical significance, supporting the results of the MICROCHECKERcorrected data (Table 1).

\section{Temporal stability}

To evaluate temporal stability between years of sampling, we analyzed and compared new samples (using the techniques described in Buresch et al. 2006) collected at Woods Hole (Buresch et al. unpubl. data) during 3 different time periods: (1) summer of 1999, (2) summer of 2000, and (3) winter of 2000. This gave us 3 samples from the same location to examine tempo-
Rodhouse 2005) could generate the differences in gene frequencies between years reported by Buresch et al. (2006).

Although the lack of temporal stability in the 1999/2000 sample at Woods Hole indicates that there is no discrete spawning unit at this particular location, the distinct groups found by Buresch et al. (2006) indicate that there may be 'family groups' that are traveling together but do not return to the same sites every year. The existence of such genetically distinct groups should be an important consideration for fisheries management.

\section{Concluding remarks}

The reasons for the discrepancy of population differentiation between the datasets of Shaw et al. (2010) and Buresch et al. (2006) are not clear. Possibly, the
Table 2. Doryteuthis pealeii. Differences among population samples collected at Woods Hole (MA, USA) in summer 1999, summer 2000 and winter 2000

\begin{tabular}{|c|c|c|c|c|c|}
\hline $\begin{array}{l}\text { Popula- } \\
\text { tion } 1\end{array}$ & $\begin{array}{l}\text { Popula- } \\
\text { tion } 2\end{array}$ & $D_{\text {EST }}$ & $\begin{array}{c}\text { Confidenc } \\
-95 \%\end{array}$ & $\begin{array}{l}\text { e interval } \\
+95 \%\end{array}$ & $F_{\mathrm{ST}}$ \\
\hline Winter 2000 & Summer 2000 & 0.04 & 0.003 & 0.087 & 0.009 \\
\hline Winter 2000 & Summer 1999 & 0.07 & 0.021 & 0.12 & 0.025 \\
\hline Summer 2000 & Summer 1999 & 0.13 & 0.077 & 0.188 & 0.059 \\
\hline
\end{tabular}


discrete populations sampled by Buresch et al. (2006) may have been mixed up by storm events or unusual current regimes before being sampled again by Shaw et al. (2010). Given the commercial value of the Doryteuthis pealeii squid fishery in the northeastern USA (ca. \$30 million annually), additional rigorous genetic studies over several years - combined with future, refined genetic methodology - need to be undertaken so that management can be improved.

\section{LITERATURE CITED}

Boyle PR, Rodhouse P (2005) Cephalopods: ecology and fisheries. Blackwell, London

Buresch KC, Gerlach G, Hanlon RT (2006) Multiple stocks of longfin squid Loligo pealeii in the NW Atlantic: stocks

Editorial responsibility: Christine Paetzold,

Oldendorf/Luhe, Germany segregate inshore in summer, but aggregate offshore in winter. Mar Ecol Prog Ser 310:263-270

Chapuis MP, Estoup A (2007) Microsatellite null alleles and estimation of population differentiation. Mol Biol Evol 24: 621-631

Gerlach G, Jüterbock A, Krämer P, Deppermann J, Harmand $P$ (2010) Calculations of population differentiation based on $G_{\mathrm{ST}}$ and $D$ : Forget $G_{\mathrm{ST}}$ but not all of statistics! Mol Ecol 19:3845-3852

Jost L (2008) $G_{\mathrm{ST}}$ and its relatives do not measure differentiation. Mol Ecol 17:4015-4026

Shaw PW, Hendrickson L, McKeown NJ, Stonier T, Naud MJ, Sauer WHH (2010) Discrete spawning aggregations of loliginid squid do not represent genetically distinct populations. Mar Ecol Prog Ser 408:117-127

van Oosterhout C, Hutchinson WF, Wills DPM, Shipley P (2004) MICRO-CHECKER: software for identifying and correcting genotyping errors in microsatellite data. Mol Ecol Notes 4:535-538

Submitted: September 28, 2011; Accepted: February 7, 2012 Proofs received from author(s): March 6, 2012 